\title{
Phytochemical, antifungal and antibacterial potential of Leptadenia hastata stem-bark extract
}

\begin{abstract}
Objectives: The Plant of genus Leptadenia belongs to family of Asclepiadaceae and have been widely employed for controlling various disease. Objective of the present study was to do preliminary phytochemical screening, Antifungal and Antibacterial potential of Hexane stem bark extract of Leptadenia hastata.

Methods: hastata extracts were evaluated for potential antifungal and antimicrobial properties. The stem-bark of the plant were extracted with five solvent of various polarity and then vaporized to give respective extracts. Antimicrobial activity against Escherichia coli, salmonella typhi staphylococcus aureus and Klebsielia pneumonia (Bacteria) and Aspergillus niger, aspergillus flavus, candida tropicalis and Fusarium oxysporium (fungi) was determined by an agar well diffusion method. The optical density of the broth using UV mini spectrophotometer and zone of inhibition by the crude extract were determined.
\end{abstract}

Results: The results showed qualitative phytochemical analysis of the extract thus, confirms the presence of various phytochemicals like sterols, terpenoids, alkaloids, flavonoids, phenols, carbohydrates, tannins, Proanthocyanidins and glycosides in its n-hexane extract. Whereas saponins was found to be absent. The extract at different concentration, showed higher significant antifungal activity against Aspergillus flavus and Aspergillus niger at $25 \mathrm{ppm} 50 \mathrm{ppm} 100 \mathrm{ppm}$ and $500 \mathrm{pmm}$ with an inhibition rate of 3.22 $\pm 0.04 \mathrm{ad}, 3.47 \pm 0.05 \mathrm{ad}, 3.55 \pm 0.05 \mathrm{ad}, 3.00 \pm 0.09 \mathrm{ad}$ (Aspergillus Flavus) and $3.08 \pm 0.04 \mathrm{a}, 3.27 \pm 0.05 \mathrm{a}, 3.32 \pm 0.08 \mathrm{ab}, 2.82 \pm 0.08 \mathrm{a}$ (Aspergillus niger) respectively at day five over the other pathogens.

Conclusion: Qualitative phytochemical screening analysis of this plant confirms the presence of various phytochemicals like alkaloids, flavonoids, phenols, flavonoids, tannins, terpenoids, sterols, carbohydrates, Proanthocyanidins and glycosides in its hexane extract which gave the plant extracts its potential against various disease. This study draws attention to the need for further studies of the active secondary metabolites identified in the reported species for the treatment of many diseases, also to understand their mechanism of action in controlling various dreadful diseases

Keywords: hexane extract, phytochemical, leptadenia hastata, secondary metabolites, antifungal, antibacterial

\author{
Volume 4 Issue 4 - 2018
}

\author{
Isaac John Umaru,' Fasihuddin A Badruddin,' \\ Hauwa Aduwamai Umaru² \\ 'Faculty of Resource Science and Technology, University of \\ Malaysia Sarawak, Malaysia \\ 2Department of biochemistry, Modibo Adama University of \\ Technology Yola Adamawa state, Nigeria
}

Correspondence: Isaac John Umaru, Faculty of Resource Science and Technology, University of Malaysia Sarawak, Kuching, 94300, Kota Samarahan Malaysia, Email umaruisaac@gmail.com

Received: June 16,2018| Published: July 24, 2018

\section{Introduction}

Medicinal plants represent a rich source of Phytochemical and antimicrobial agents. Plants are used medicinally in different countries and are a source of many potent and powerful drugs. ${ }^{1} \mathrm{~A}$ wide range of medicinal plant parts is used for extract as raw drugs and they possess varied medicinal properties. While some of these raw drugs are collected in small quantities by the local communities and traditional healers for local use. ${ }^{2}$ Considering the vast potentiality of plant as sources for antimicrobial drugs with reference to antibacterial and antifungal agents, the plant Leptadenia hastata was undertaken to screen the local flora for its antifungal, antibacterial activity as well as the phytochemical screening. This situation provided the impetus to the search for new antimicrobial substances from various sources like Leptadenia hastata stem-bark. ${ }^{3}$ Leptadenia hastata (Pers) Decne (Family-Asclepiadaceae), commonly known as hastata is an edible non-domesticated vegetable and it is collected in wild throughout Africa. ${ }^{4}$ Leptadenia hastata is a voluble herb with creeping latex stems, glabescent leaves, glomerulus and racemus flowers as well as follicle fruits. It is typically grown in tropical dry lands in sandy soil. ${ }^{5}$ Wild foods like Leptadenia hastata provide food security during seasonal changes and are used medicinally in many areas. The breeders commonly used the leaf and stems for their parasitic activity and against placental retention. ${ }^{6-8}$

Plants contain many active compounds such as alkaloids, steroids, tannins, glycosides, volatile oils, fixed oils, resins, phenols flavonoids etc, which are deposited in their specific parts such as leaves, flowers, bark, seeds, fruits, root, etc. The beneficial medicinal effects of plant materials typically result from the combination of these secondary products. Phytochemicals are known to possess antioxidant, ${ }^{9}$ antibacterial, ${ }^{10}$ antifungal, ${ }^{11}$ antidiabetic, ${ }^{12-14}$ anti-inflammatory. ${ }^{15}$ Objective of the present study was to do preliminary phytochemical screening, Antifungal and Antibacterial potential of Hexane stem bark extract of Leptadenia hastata. This study draws attention to the need for further studies of the active secondary metabolites identified in the reported species for the treatment of many diseases also to understand their mode of action in controlling various dreadful diseases. 


\section{Materials and methods}

\section{Collection of plant material and extraction}

The stem-bark of the collected plants were separated, washed carefully with tap water, rinsed with distilled water, air dried for 1hour, and shade dried. They were ground in to powder (coarsely) and stored at room temperature.

\section{Preparation of sample}

The freshly dried stem-bark of Leptadenia hastata was grounded into fine powdered form using laboratory mortar and pestle and electric blender. $150 \mathrm{mg}$ of the powdered stem-bark was weighed into a beaker and mixed with distilled water three times the quantity of the sample and allow to stand for two days with continues shacking at time interval for $12 \mathrm{hrs}$. The mixture was then filtered using Whatman filter paper No.4 and the solvent was then evaporated using a rotary evaporator (Heldolph Laborato 400). It was then stored under frozen condition for further use.

\section{Reconstitution of the extracts}

$2 \mathrm{~g}$ of the extract was weighed and dissolved in $20 \mathrm{ml}$ of $50 \%$ Dimethyl sulfoxide (DMSO) to make a stock concentration of $100 \mathrm{mg} /$ $\mathrm{ml}$ from which the various concentrations used were calculated.

\section{Microorganisms used}

Isolates of Aspergillus flavin, Aspergillus niger, Candida tropicalis, and Fusarium oxysporium (Fungi) and Salmonella typhi, Escherichia coli, Staphylococcus aureus, Klebsielia Pneumonia from four different Concentration were used. They were collected from Virology and Microbiology Laboratory Faculty of Resource Science and Technology Universiti Malaysia Sarawak.

\section{Sterilization of materials used}

All glass wares were thoroughly washed in water containing detergent and rinsed with distilled water, they were air dried and sterilized in the oven at $160^{\circ} \mathrm{c}$ for one hour. Inoculating chamber and growth chamber were fumigated using formaldehyde and then irradiated on exposure to UV lamp for one hour. Laboratory benches were cleaned with absolute alcohol while the inoculating loop was flamed to redness and allowed to cool prior to use.

\section{Drug used}

Fluconazole common name Diflucan (Pfizer Inc New York, NY) and antibacterial agent $(30 \mu \mathrm{g})$ tetracycline, antimicrobial susceptibility test discs and Nutrient agar (CM0003) were obtained from Oxoid Ltd, Wade Road, Basingstoke, Hants, RG2 8PW, UK.

\section{Reagent preparation for phytochemical analysis}

1\% ammonia: $1 \mathrm{ml}$ of ammonia dissolved in $99 \mathrm{ml}$ of distilled water. $1 \%$ ammonium chloride: $1 \mathrm{~g}$ of ammonium chloride was dissolved in $100 \mathrm{ml}$ distilled water.

Mayer's reagent: It is used for the detection of alkaloids. Solution (a) $1.36 \mathrm{~g}$ of mercuric chloride is dissolved in $60 \mathrm{ml}$ of distilled water. (b) $5 \mathrm{~g}$ of potassium iodide is dissolved in $20 \mathrm{ml}$ of distilled water. Solution (a) and (b) are mixed and the volume was adjusted to $100 \mathrm{ml}$ with distilled water.

Wagner's reagent: It is a general reagent for the detection of alkaloids. $1.27 \mathrm{~g}$ of iodine and $2 \mathrm{~g}$ of potassium iodide was dissolve in $5 \mathrm{ml}$ of water and the volume was made $100 \mathrm{ml}$ with distilled water.

Fehling's solution: It is used for the detection of reducing sugars. $34.66 \mathrm{~g}$ of copper sulphate is dissolved in distilled water and the volume was made to $500 \mathrm{ml}$ (Solution-a). $173 \mathrm{~g}$ of potassium sodium tartrate and $50 \mathrm{~g}$ of sodium hydroxide in $\mathrm{D} / \mathrm{W}$ was dissolved and volume was made up to $500 \mathrm{ml}$ (solution -b). The two solutions were mixed in equal volume for prior use.

Ferric Chloride (alcoholic): A 5\% w/v solution of ferric chloride in $90 \%$ alcohol is used for the detection of phenols. Lead acetate: A $25 \%$ basic lead acetate solution is used for the detection of flavonoid.

\section{Tests for phytochemical Screening}

Test for Sterols: Two tests was used the Salkowski test and Liebermann-Burchard test. The Test didn't give positive result confirming the absence of Sterols. The salkowski test: In $2 \mathrm{ml}$ of plant extract, $2 \mathrm{ml}$ of chloroform and $2 \mathrm{ml}$ of concentrated $\mathrm{H}_{2} \mathrm{SO}_{4}$ was added and shaken well. Chloroform layer didn't appear red and acid layer greenish yellow fluorescent. Thus sterols were absent. However, the Liebermann-Burchard Test: $2 \mathrm{ml}$ of the extract was mixed with chloroform. 1-2ml acetic anhydride and 2 drops of concentrated $\mathrm{H}_{2} \mathrm{SO}_{4}$ from the side of the test tube was added in the mixture. The red, blue and finally green colour was not observed indicates the presence of sterols.

Test for Terpenoids: This was determined by Salkowski test which gave a positive result thus confirms the presence of Terpenoids. The extract was also mixed with $2 \mathrm{ml}$ of chloroform and concentrated $\mathrm{H}_{2} \mathrm{SO}_{4}(3 \mathrm{ml})$ is carefully added by through the side to form a layer. A reddish brown colouration of the interface was formed which confirm positive result of the presence of terpenoids.

Test for Alkaloids: Mayer's reagent \& Wagner's reagent was used to confirm the presence of Alkaloids in the extract. The Methanol plant extract was warmed with $2 \% \mathrm{H}_{2} \mathrm{SO}_{4}$ for two minutes. It is filtered and few drops of reagents were added separately. (a). Mayer's reagent-A creamy- white coloured precipitation appeared giving a positive result. (b). Wagner's reagent-gave a reddish-brown precipitate which confirms the presence of alkaloids in the extract.

Test for Carbohydrates: In determining the presence of carbohydrate, Molisch test and Fehling's test was used.

Molisch test: Extract was treated with few drops of alcoholic alpha-naphthol and $0.2 \mathrm{ml}$ of concentrated sulphuric acid was added slowly along the sides of test tube, purple to violet colour ring was observed at the junction.

Fehling's test: The Fehling A and Fehling B reagents were mixed and few drops of extract was added and boiled. A brick red coloured precipitate of cuprous oxide forms was observed thus confirms the presence of carbohydrates.

Test for flavonoids: In the test for Flavonoid in this extract Ammonium Test and Aluminium Chloride Test did confirm the presence of flavonoids in the Hexane extract. A small quantity of the extract is heated with $10 \mathrm{ml}$ of ethyl acetate in boiling water for 3 minutes. The mixture is filtered and the filtrates are used for the following test.

Ammonium test: The filtrate was shaken with $1 \mathrm{ml}$ of dilute ammonia solution (1\%). The layers were allowed to separate. A yellow colouration was observed at ammonia layer which indicates the presence of the flavonoid from the plant extract. 
Aluminium chloride test: The filtrates were shaken with $1 \mathrm{ml}$ of $1 \%$ aluminium chloride solution and a light yellow colour did appear indicating the presence of flavonoids. The light yellow colour indicates the presence of flavonoid and when dilute $\mathrm{NaOH}$ and $\mathrm{HCl}$ is added the yellow solution turns colourless.

Test for tannins: Ferric Chloride Test and Lead Sub Acetate Test are test to confirm the presence of Tannins in the plant extract. A small quantity of the extract is boiled with $5 \mathrm{ml}$ of $45 \%$ solution of ethanol for 5 minutes. Each of the mixture was cooled and filtered. The different filtrates were used for the following test:

Ferric chloride test: $1 \mathrm{ml}$ each of filtrate is diluted with distilled water and two drops of ferric chloride is added. A transient greenish to black colour indicated the presence of Tannins.

Lead Sub acetate test: $1 \mathrm{ml}$ of the different filtrate was added with three drops of lead sub acetate solution. A creamy gelatinous precipitation, indicates positive test for Tannins.

Test for phenols: Phenols was present in the hexane extract.

Ellagic acid test: The test solution was treated with few drops of $5 \%(\mathrm{w} / \mathrm{v})$ glacial acetic acid and $5 \%(\mathrm{w} / \mathrm{v}) \mathrm{NaNO}_{2}$ solution. The solution did turn muddy with Niger brown precipitate occurred. Hence, the presence of phenols was confirmed.

Test for glycosides: The Keller-Kiliani Test and Concentrate $\mathrm{H}_{2} \mathrm{SO}_{4}$ Test was used to confirmed the presence of Glycosides in the hexane extract.

Keller-kiliani test: In $2 \mathrm{ml}$ of the plant extract, glacial acetic acid, one drop of $5 \% \mathrm{FeCl}_{3}$ and conc. $\mathrm{H}_{2} \mathrm{SO}_{4}$ were added. Reddish brown colour appears at junction of the two liquid layers and upper layer appears bluish green, confirming the presence of glycosides. However, in Conk $\mathrm{H}_{2} \mathrm{SO}_{4}$ Test: $\mathrm{In} 5 \mathrm{ml}$ plant extract, $2 \mathrm{ml}$ glacial acetic acid, one drop of $5 \% \mathrm{FeCl}_{3}$ and Conc. $\mathrm{H}_{2} \mathrm{SO}_{4}$ were added. Brown ring appears, indicating the presence of glycosides.

Test for saponin: Foam test and haemolytic test were conducted which gave a negative result. Foam Test: The extract was diluted with $20 \mathrm{ml}$ of distilled water and it was shaken in a graduated cylinder for 15 minutes. A layer of foam was not formed which indicated the absence of Saponin. In the haemolysis Tests: - Hexane extract was added to one drop of blood placed on a glass slide. Haemolytic zone did not appeared. The test confirms that Saponin is absent in the extract.

Test for proanthocyanidins: Proanthocyanidins test was based on the Sun et al., ${ }^{16}$ procedures. Exactly $0.5 \mathrm{ml}$ of $0.1 \mathrm{mg} / \mathrm{ml}$ of extract solution was mixed with $3 \mathrm{ml}$ of $4 \%$ vanillin-methanol solution and $1.5 \mathrm{ml}$ hydrochloric acid. The mixture was allowed to stand for $15 \mathrm{~min}$. The absorbance was read at $500 \mathrm{~nm}$. Total proanthocyanidins contents were calculated as tannic acid equivalents $(\mathrm{mg} / \mathrm{g})$.

\section{Preparation of test samples for antibacterial studies}

The crude extracts of Leptadenia hastata was used in antibacterial assay namely the hexane, dichloromethane, ethyl acetate, chloroform and methanol crude extracts. The crude extracts were tested by disc diffusion method on nutrient agar medium as described by Ram Kumar \& Pranay. ${ }^{17}$

The plant exactly $5 \mathrm{mg}$ of each crude sample were dissolved homogeneity in $5 \mathrm{~mL}$ of methanol giving a stock solution of $1000 \mu \mathrm{g} /$
$\mathrm{mL}$. lower concentration of $25,50,100,250,500$, and $1000 \mathrm{ppm}$, i.e. Six different volumes from the stock solution were taken for the studies.

\section{Preparation of agar plates}

Preparation of agar plates was performed based on method described by Ram Kumar \& Pranay. ${ }^{17}$ Nutrient agar was prepared according to manufacturer's instruction with $14 \mathrm{~g}$ of dried agar dissolved in $500 \mathrm{~mL}$ distilled water. The agar solution was heated until boiling followed by sterilization in autoclave at $121^{\circ} \mathrm{C}$. The agar solution was then poured into a sterile petri plate and allowed to cool down and forming a gel. The plate was divided into eight sections by making a line marking on the outside surface of the plate. The six sections were for each test samples namely the $25 \mathrm{ppm}, 50 \mathrm{ppm}, 100 \mathrm{ppm}, 250 \mathrm{ppm}, 500 \mathrm{pp}$ and $1000 \mathrm{ppm}$ samples, tetracycline $30 \mu \mathrm{g}$ (positive control) and methanol (negative control). The plate was sealed using parafilm and keep chilled at $4^{\circ} \mathrm{C}$ upon bacteria inoculation.

\section{Preparation of bacteria broth}

The selected bacteria were used to evaluate the antibacterial activity of the crude extracts of Leptadenia hastata, Staphylococcus aureus (ATCCO25923 were obtained from the stock culture provided by Virology Laboratory, Universiti Malaysia Sarawak. The nutrient broth was prepared according to manufacturer's instruction, with 2.6 $\mathrm{g}$ of the dried broth dissolved in $200 \mathrm{~mL}$ distilled water followed by sterilization in autoclave at $121^{\circ} \mathrm{C}$. The bacterial was sub-cultured in a $10 \mathrm{~mL}$ of broth, each in universal glass vail bottle for 16 hours inside an incubator equipped with shaker at $37^{\circ} \mathrm{C} .{ }^{18}$

After 16 hours' incubation, turbidity (optical density/OD) of the bacterial broth was measured by using UV mini spectrophotometer (model 1240 of Shimadzu brand), comparable to that of nutrient broth standard tube for further use. ${ }^{19}$ The measurement of the optical density was performed at wavelength $575 \mathrm{~nm}$ and the bacterial broth was ready to be used when its turbidity was between OD 0.6 to 0.9 . Nutrient broth was used to adjust the turbidity until the desired value was obtained.

\section{Plate inoculation}

Inoculation of the bacteria was carried out in a biohazard cabinet and the procedure was based on method described by Ram Kumar \& Pranay. ${ }^{17}$ Approximately $1 \mathrm{~mL}$ of the ready bacterial broth were transferred into mini centrifuge tubes. A sterile cotton swap was dipped into the mini centrifuge tube containing bacteria broth and streaked over entire of the agar plate surface, performed in 4 different directions. The agar plate was then left for 5-10 minutes before applying the test samples. The disc used was $6 \mathrm{~mm}$ diameter. A volume of $10 \mu \mathrm{L}$ of the test samples of concentration $10,25,50,100,250,500$ and $1000 \mu \mathrm{g} / \mathrm{mL}$ were each pupated onto the discs and placed onto the agar plate by using sterile forceps and gently pressed to ensure contact. Next to be placed on the agar plate was the disc pupated with methanol as negative control, followed by $30 \mu \mathrm{g}$ of tetracycline as standard antibacterial agent (positive control). The plates were left at room temperature for 10 minutes to allow the diffusion of the test samples and the standards into the agar. Each crude extract was tested in triplicate for the bacterium used. The plate samples were then incubated at $37^{\circ} \mathrm{C}$ for 24 hours before the inhibition zone around every sample disc being examined. The inhibition zone was measured in diameter $(\mathrm{mm})$ to indicate the presence of antibacterial activity for each sample, as compared to the positive control. 


\section{Antifungal potential}

The antifungal potential of the plant extract was performed by agar disc diffusion method as reported by Umaru et al., ${ }^{20}$ Dimethyl sulfoxide DMSO was used as a negative control and Fluconazole (Diflucan) was used as a positive control. The plates were incubated at $37^{\circ} \mathrm{C}$. The fungal activity was taken on the basis of diameter of zone of inhibition in triplicate, which was measured before and after 5 days of incubation and the mean of three readings is presented. The presence of inhibition of the treated fungus was calculated using positive control as standard (100\% inhibition). ${ }^{21-23}$ The plant extract and the standard antifungal agents were dissolved in DMSO, 100\% biologically inert substances, with the disc diameter of $6 \mathrm{~mm}$. The extracts were separately dissolved in dimethyl sulphoxide. This (DMSO) solvent served as reference control for the antifungal study. The solvent control (DMSO) was also maintained throughout the experiment. Potato dextrose agar media was used for the antifungal study. The molten media was then inoculated with $200 \mu \mathrm{l}$ of the inoculums $(1 \times 108 \mathrm{Cfu})$ and poured into the sterile Petri plates. The disc was saturated with $20 \mu$ l of the extracts separately, allowed to dry and was introduced on the upper layer of the seeded agar plate. The plates were incubated at $28^{\circ} \mathrm{C}$ and the zone of inhibition was measured every after $24 \mathrm{~h}$ for five days.

\section{Fungal preparation}

The fungi were standardized by inoculating sterile normal saline solution with a $48 \mathrm{~h}$ pure culture by adjustment of turbidity to match $0.5 \mathrm{McF}$ arland stand Standardization of the microorganisms included harvesting fungal spores from a 7 days old culture on SDA slant. Ten milliliters of sterile normal saline containing 3\% w/v Tween 80 was used to disperse the spores with the aid of sterilized glass beads. ${ }^{24}$ Standardization of the spore suspension to $1.0 \times 106$ spores $/ \mathrm{mL}$ was achieved with a UV spectrophotometer (Spectronic 20D; Milton

Table I Qualitative analysis of phytochemical components of Leptadenia hastata
Roy Company, Pacisa, Madrid, Spain) at 530nm (OD at 530) of the suspensions and adjusted to a transmittance of $70-72 \%$. The plates were incubated at $37^{\circ} \mathrm{C}$ for $24 \mathrm{~h} .{ }^{25}$

\section{Statistical analysis}

Values were expressed as Mean \pm standard deviation for three determinations of each experiment. The analysis was done using the software-SPSS one-way ANOVA

\section{Result and discussion}

\section{Results (Tables 1-3)}

\section{Discussion}

Phytochemicals have received an increasing attention because of interesting new discoveries considering their biological activities. ${ }^{26}$ In this studies a number of phytochemical are present while some are absent like sterol and saponin. The extract of this plant Leptadenia hastata shows a remarkable antifungal and antibacterial activities as a result of a number of Phytochemical shown above in Table 1. They constitute a major group of compounds that act as a primary antioxidant with redox potentials..$^{27}$ The study on the stem-bark extract of Leptadenia hastata revealed that this plant contains a substantial amount of bioactive compound such as phenols which was linked with antioxidant activity of plants. ${ }^{28}$ Thus, it was believed to have improved health and nutrition through the consumption of this herbs of such plants. ${ }^{29}$ Reasonable amount of these phytochemicals observed in this study, is an indication of the potential of Leptadenia hastata in the management of diseases related to the accumulation of free radicals in the body including diabetes mellitus, antitumor, anti-mutagenic and antifungal, antibacterial potentials as shown in Table $2 \& 3$.

\begin{tabular}{llc}
\hline Serial Number & Phytochemical components & Result \\
\hline A & Sterols & - \\
B & Terpenoids & ++ \\
C & Alkaloids & +++ \\
D & Carbohydrate & +++ \\
E & Flavonoids & ++ \\
F & Tannins & + \\
G & Phenols & ++ \\
H & Glycosides & + \\
I & Saponins & - \\
J & Proanthocyanidins & ++ \\
\hline$(++)$ Strongly present; (+) Wealy Present (-)Absent
\end{tabular}

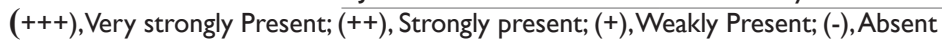

Table 2 Effect of hexane stem bark extract of Leptadenia hastata on fungi

\begin{tabular}{lllllllll}
\hline \multicolumn{7}{c}{ Concentration (ppm) } \\
\hline Organisms & Day & Control & $\mathbf{2 5}$ & $\mathbf{5 0}$ & $\mathbf{1 0 0}$ & $\mathbf{2 5 0}$ & $\mathbf{5 0 0}$ & 1000 \\
\hline & 1 & $0.50 \pm 0.00$ & $0.42 \pm 0.04$ & $0.38 \pm 0.04$ & $0.30 \pm 0.06$ & $0.32 \pm 0.04$ & $0.23 \pm 0.05$ & $0.20 \pm 0.05$ \\
& 2 & $0.60 \pm 0.09$ & $0.60 \pm 0.06$ & $0.68 \pm 0.04$ & $0.77 \pm 0.05^{\mathrm{b}}$ & $0.53 \pm 0.05$ & $0.43 \pm 0.05$ & $0.28 \pm 0.04$ \\
Aspergillus niger & 3 & $1.55 \pm 0.05$ & $1.53 \pm 0.05$ & $1.47 \pm 0.12$ & $1.48 \pm 0.04$ & $1.43 \pm 0.08$ & $0.95 \pm 0.05$ & $0.40 \pm 0.00$ \\
& 4 & $2.48 \pm 0.10$ & $2.60 \pm 0.06$ & $2.68 \pm 0.04$ & $2.73 \pm 0.08^{\mathrm{b}}$ & $2.02 \pm 0.04$ & $1.53 \pm 0.05$ & $0.93 \pm 0.05$ \\
& 5 & $3.13 \pm 0.08$ & $3.08 \pm 0.04^{\mathrm{a}}$ & $3.27 \pm 0.05^{\mathrm{a}}$ & $3.32 \pm 0.08^{\mathrm{ab}}$ & $2.82 \pm 0.08^{\mathrm{a}}$ & $1.98 \pm 0.04^{\mathrm{a}}$ & $1.12 \pm 0.12^{\mathrm{a}}$
\end{tabular}


Table continued..

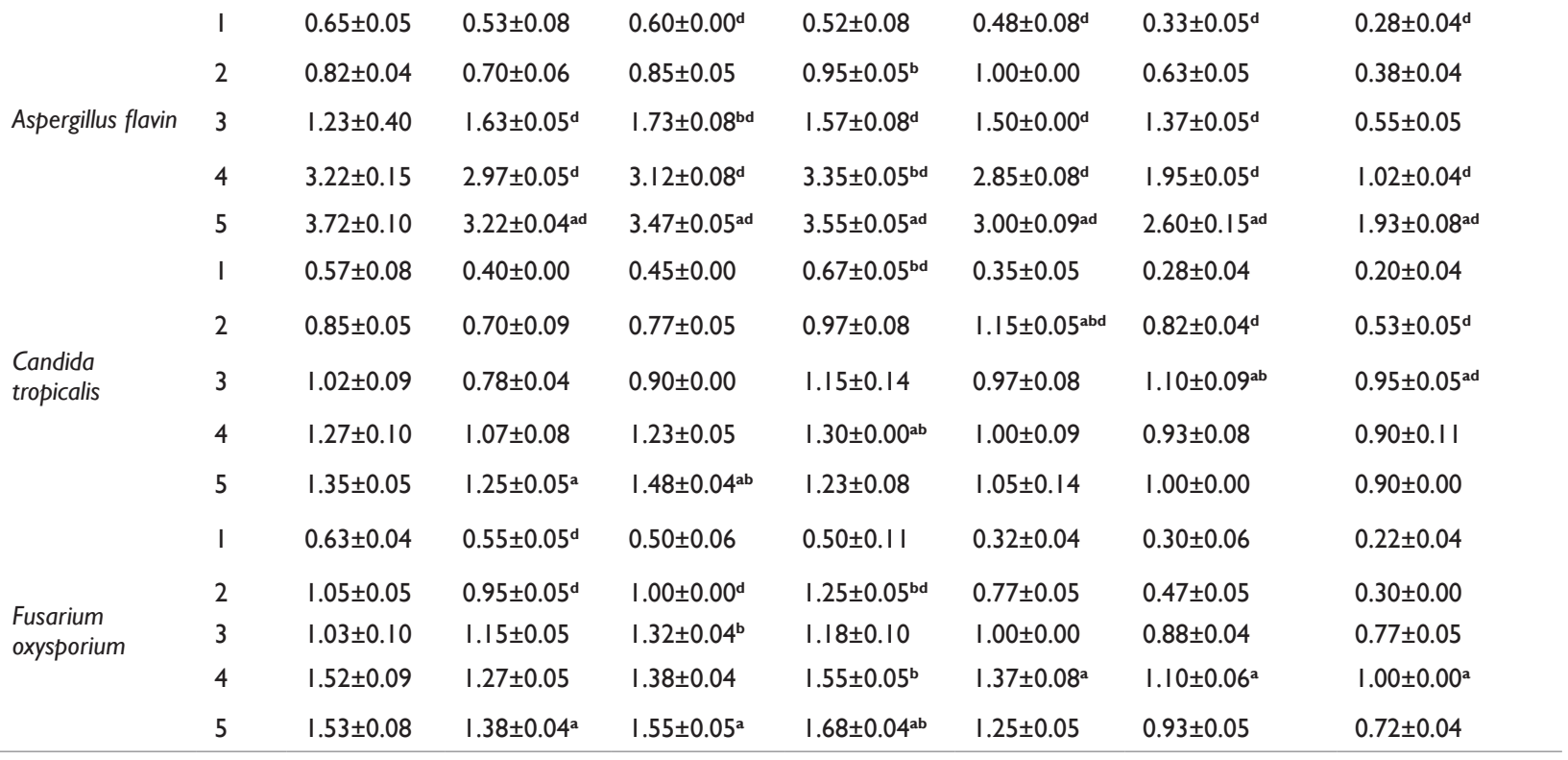

Values are Mean $\pm S D$ for six determinations

aSignificantly $(p<0.05)$ higher compared to different treatment days at the same concentration on each fungi

${ }^{b}$ Significantly $(p<0.05)$ higher compared to the control on each fungus in each row

${ }^{d}$ Significantly $(p<0.05)$ higher compared to other fungi on the same day on each concentration.

Table 3 Effect of hexane stem bark extract of Leptadenia hastata on bacteria

\begin{tabular}{|c|c|c|c|c|c|c|c|}
\hline \multirow[b]{2}{*}{ Organism } & \multirow[b]{2}{*}{ Control } & \multicolumn{5}{|c|}{ Concentration (ppm) } & \multirow[b]{2}{*}{1000} \\
\hline & & 25 & 50 & 100 & 250 & 500 & \\
\hline Salmonella typhi & $2.01 \pm 0.02$ & $0.57 \pm 0.06$ & $0.73 \pm 0.12$ & $0.80 \pm 0.10$ & $0.97 \pm 0.12$ & $1.03 \pm 0.06$ & $1.13 \pm 0.06$ \\
\hline Escherichia coli & $2.04 \pm 0.00$ & $0.57 \pm 0.06$ & $0.67 \pm 0.06$ & $0.73 \pm 0.06$ & $0.90 \pm 0.00$ & $1.03 \pm 0.06$ & $1.23^{\mathrm{a}} \pm 0.06$ \\
\hline Staphylococcus aureus & $2.06 \pm 0.01$ & $0.70^{\mathrm{a} \pm} 0.00$ & $0.93 \pm 0.12$ & $1.00 \pm 0.20$ & $1.17^{a} \pm 0.06$ & $1.16 \pm 0.12$ & $1.27^{\mathrm{a} \pm} 0.06$ \\
\hline Klebsielia Pneumonia & $2.06 \pm 0.03$ & $0.73 \pm 0.12$ & $0.87 \pm 0.31$ & $1.10 \pm 0.10$ & $1.13 \pm 0.12$ & $1.13 \pm 0.12$ & $1.13 \pm 0.21$ \\
\hline
\end{tabular}

Values are Mean $\pm S D$ for three determinations

aSignificantly $(p<0.05)$ higher compared to the extract at the same concentration in each.

The result produced a remarkable inhibition rate against the tested species of microorganisms between 25ppm-1000ppm given concentration when compared to the test control. The antifungal activities of this plant extract Table 2, revealed the extract possess antifungal potential in concentration dependent manner against the test organism and was comparable with the standard drug. The inhibition yielded at concentration $25 \mathrm{ppm}-250 \mathrm{ppm}$ was found to be active against all tested strains under study. However, the extract showed higher significant antifungal activity against Aspergillus flavus and Aspergillus niger at 25ppm 50ppm 100ppm and 500pmm with an inhibition rate of $3.22 \pm 0.04 \mathrm{ad}, 3.47 \pm 0.05 \mathrm{ad}, 3.55 \pm 0.05 \mathrm{ad}$, $3.00 \pm 0.09 \mathrm{ad}$ (Aspergillus Flavus) and $3.08 \pm 0.04 \mathrm{a}, 3.27 \pm 0.05 \mathrm{a}$, $3.32 \pm 0.08 \mathrm{ab}, 2.82 \pm 0.08 \mathrm{a}$ (Aspergillus niger) respectively at day five over the other pathogens. Though the extract showed moderate activity at all concentration on the fungal species, the potency exhibited less significant activity against Candida tropicalis as well as Fusarium oxysporium strains. However, this positive result was believed to be as a result of the presence of these phytochemical obtained in the plants extract which was also confirmed to be by some researchers, ${ }^{30-32}$ in their studies on Leptadenia hastata ariel parts. Similarly, the antibacterial activity results of the extracts as summarized by the paper disc diffusion methods shown in the tables above. The results of the disc diffusion method in terms of the size zone of inhibition $(\mathrm{mm})$ for the extracts were compared against the bacteria's studied. In this study Escherichia coli and Staphylococcus aureus showed higher inhibition activity respond with inhibition rate of $1.23 \pm 0.06 \mathrm{~mm}$ and $1.27 \pm 0.06 \mathrm{~mm}$ respectively at $100 \mathrm{ppm}$ when compared to the control $2.04 \pm 0.00,2.06 \pm 0.01$ and other two bacteria at the same extract concentration.

\section{Conclusion}

The phytochemical screening has shown the potential of the extract that lead to its activities as antifungal and antibacterial as observed in this study. The secondary metabolite studies have shown that the Carbohydrates, Flavonoids, Alkaloids, Tannins, Steroids, Phenol and Proanthocyanidins are of great importance in the field of Biological activities as well as drug research. These classes, Alkaloids, Saponin, Tannins, Flavonoids are known to have activity against pathogens and therefore aid the antimicrobial activities of medicinal plants. ${ }^{33}$ In these studies of phytochemical screening, antifungal and antibacterial potentials we found that the hexane extract of Leptadenia hastata stem-bark possess, terpenoids, Alkaloids, carbohydrates, glycoside, Proanthocyanidins and tannins. This suggests that stem bark of Leptadenia hastata based on this study possess antifungal and antibacterial activities and may possess anti-inflammatory, analgesic, antidiarrhoeal, antioxidant, immunomodulatory, anthelmintic and anti-tumour activities. However further studies are required in this 
direction for its comprehensive analysis, which characterize its chemical structure.

\section{Acknowledgements}

The authors are thankful to ZAMALA and the Natural Product laboratory FRST/FSTS University Malaysia Sarawak for the enabling support to carry out this study.

\section{Conflict of interest}

The author declares that there is no conflict of interest.

\section{References}

1. Srivastava J, Lambert J, Vietmeyer N. Medicinal plants: An expanding role in development. World Bank Technical Paper. 1996. p. 320.

2. Rekha, Krishan K, Monika S. Antifungal Potential of Leptadenia Pyrotechnica against Some Pathogenic Fungi. International Journal of Engineering Science Invention. 2013;2(5):27-29.

3. Gonzalez CE, Venzon D, Lee S, et al. Risk factors for fungemia in children infected with human immunodeficiency virus: a case control study. Clin Infect Dis. 1996;23(1):515-521.

4. Freiberger CE, Vandergagt DJ, Pastuszyn A, et al. Nutrient content of edible leaves of seven wild plants from Niger. Plant Foods Hum Nutr. 1998;53(1):57-69.

5. Freiberger CE, Vanderjagt DJ, Pastuszyn A, et al. Nutrient content of the edible leaves of seven wild plants from Niger. Plant Foods Hum Nutr. 1998;53(1):57-69.

6. Kerharo J, Adam JG. La pharmacopée sénégalaise traditionnelle: plantes médicinales et toxiques. Vigot et frères editor. Paris. 1974. p. 1011.

7. Arbonnier M. Trees, shrubs and lianas of West African dry zones. Editions Quae; 2004.

8. Bayala B, Rubio-Pellicer MT, Zongo M. Anti-androgenic activity of Leptadenia hastata (Pers.) Decne: competitive effect of the aqueous extracts of the plant and the testosterone propionate on castrated immature rats. Biotechnologie Agronomie, Société et Environnement. 2011;15(2):223-9.

9. Wong SK, Lim YY, Chan EW. Antioxidant properties of Hibiscus: species variation, altitudinal change, coastal influence and floral colour change. Journal of tropical forest science. 2009;21(4):307-15.

10. Nair R, Kalariya T, Chanda S. Antibacterial activity of some selected Indian medicinal flora. Turkish Journal of biology. 2005 Mar 28;29(1):417.

11. Khan M, Wassilew SW, Schmutterer H. Natural pesticides from the neem tree and other tropical plants. GTZ, Germany: Eschborn; 1987:645-50.

12. Singh N, Gupta M, Sirohi P. Effects of alcoholic extract of Momordica charantia (Linn.) whole fruit powder on the pancreatic islets of alloxan diabetic albino rats. J Environ Biol. 2008;29(1):101-106.

13. Gupta R, Bajpai KG, Johri S, et al. An overview of Indian novel traditional medicinal plants with anti-diabetic potentials. Afr J Tradit Complement Altern Med. 2008;5(1):1-17.

14. Kumar S, Kumar D, Deshmukh RR, et al. Antidiabetic potential of Phyllanthus reticulatus in alloxan-induced diabetic mice. Fitoterapia. 2008;79(1):21-23.

15. Kumar R, Chow CC, Bartels JD, et al. A mathematical simulation of the inflammatory response to anthrax infection. Shock. 2008;29(1):104.
16. Sun JS, Tsuang YW, Chen IJ, et al. An ultraweak chemiluminescene study on oxidative stress in rabbit following acute thermal injury. Burns. 1998;24(3):225-231.

17. Ram Kumar P, Pranay J. Comparative studies on the antimicrobial activity of black pepper (Piper nigrum) and turmeric (Curcuma longa) extracts. International Journal of Applied Biology and Pharmaceutical Technology. 2010;1(2):491-501.

18. Mahesh B, Satish S. Antimicrobial activity of some important medicinal plant against plant and human pathogens. World journal of agricultural sciences. 2008;4(5):839-843.

19. Vandepitte J, Engback K, Piot P. Basic Microbiology Procedures in Clinical Bacteriology. Geneva: World Health Organization; 1995. p. 85.

20. Isaac John Umaru, Fasihuddin A Badruddin, Henry Y Wakawa, et al. Antifungal Potential of Leptadenia Hastata Against Some Pathogenic Fung. American Journal of Biochemistry and Biotechnology. 2018;14(1):57-60.

21. Cruickshank R. The Practice of Medical Microbiology. 1st edn. London: Churchill Livingstone; 1975. p. 98.

22. Karwa VG, Sathawane PN, Kasture VS. Evaluation of antifungal activity by agar disc diffusion method. Indian Drugs. 1997;34:174-176.

23. Aboh MI, Olayinka BO, Adeshina GO. Preliminary studies on the antifungal activities of the phyto compounds from Mitracarpus villosus (Sw.) Dc aerial parts obtained from Abuja, Nigeria. Mal J Microbiol. 2014;10:133-138.

24. Olowosulu AK, Ibrahim YKE, Bhatia PG. Studies on the antimicrobial properties of formulated creams and ointments containing Baphia nitida heartwood extract. J Pharm Biores. 2005;2(2):124-130.

25. Aberkane A, Cuenca-Estrella M, Gomez-Lopez A, et al. Comparative evaluation of two different methods of inoculum preparation for antifungal susceptibility testing of filamentous fungi. $J$ Antimicrob Chemother. 2002;50:719-22.

26. Cho EJ, Yokozawa T, Rhyu DY, et al. Study on the inhibitory effects of Korean medicinal plants and their main compounds on the 1, 1diphenyl-2-picryl-hydrazyl radical. Phytomedcine. 2003;10(6-7):544551 .

27. Kahkonen MP, Hopia AI Vuorela, Rauha HJ, et al. Antioxidant activity of plant extracts containing phenolic compounds. J Agric Food Chem. 1999;47(10):3954-3962.

28. Li H, Song F, Ren You Gan R, et al. Total phenolic contents and antioxidant capacities of selected Chinese medicinal plants. Int J Mol Sci. 2010;11(6):2362-2372.

29. Atawodi SE. Antioxidant potential of African medicinal plants. African Journal of Biotechnology. 2005;4(2):128-129.

30. Satish S, Mohana DC, Ranhavendra MP, et al. Antifungal activity of some plant extracts against important seed borne pathogens of Aspergillus Sp. $J$ Agric Technol. 2007;3:109-119.

31. Ilyas MB, Iftikar W Anwar, Haq M. Effect of different neem products on the vegetative growth and sclerotial production of Macrophomina phaseolina. Pak J Phytopathol. 1997;9:77-79.

32. Dubey RC, Kumar R. Efficacy of Azadirachtin of sclerotia of Macrophomina phaseolina causing charcoal rot in soybean. Indian Phytopathol. 2003;56:216-217.

33. Ghosh P, Mandal A, Chakraborty P, et al. Triterpenoids from Psidium guajava with biocidal activity. Indian J Pharm Sci. 2010;72(4):504-507. 